\title{
NOTES ON THE TURKANA TRIBE OF BRITISH EAST AFRICA
}

\section{PART II.}

Occupation and Pursuits. - The chief occupation of the Turkana is the herding of stock, and, it may be added, the acquiring of it by fair means or foul. They own large herds and flocks of camels, cattle, donkeys, sheep, and gaats; are expert stockmen, and know more of animal disease than human. The extreme scarcity of water, which has to be ladled by skin buckets and wooden troughs from water holes and wells, gives enormous work, which, with the paucity of grazing, adds impetus to a desire to move further south. As much stock is probably lost by starvation as by disease. Camels, a recent acquisition, are prized and not used as baggage animals.

The grazing of cattle is done by men and youths, the watering mainly by women.

Women's work is the collection of edible berries in times of scarcity, milking, cooking, rough hut building, and the dressing of skins.

Raiding cattle from their neighbours may be described as an occupation, which has brought much trouble upon the tribe. Youths and men between 15 and 50 years take part, and instances are recorded of women accompanying the raids, presumably to herd the captured cattle. They raid on a large scale, and generally do not spare women or children, though captives are taken. Passwords are used, and probably change with each raid; the standing Turkana challenge is: (question) Tirigol? (The Turkwell River ?) (Answer) Lo'moton (In the bush).

A great deal of time at night is spent in dancing. The dances are :- 
1. Akimurmur. This is of two kinds:

a. Before a raid bullocks are killed and eaten to ensure its success. Women and girls form outside the circle of men, join hands, indulge in obscene posturing, and taunt the raiders to a frenzy.

b. A man desiring to make a feast collects his friends, hands are clasped, the dancers move in circles, various animals, as the giraffe, are imitated. The dance is one of thanksgiving.

The same dance is found with the Jie, Dodoso, Karamojo, and Suk, under the same name; the Acholi have animal dances.

2. Adonga. This is a deliberate exercise; young men and girls meet and jump up and down in a rigid fashion, keeping remarkable time, the youths boasting of their prize bullocks. (Vide Sir H. Johnston, The Uganda Protectorate, p. 852.)

The same dance and name is found with the tribes mentioned above.

3. Jiumo. This is danced at the end of the scanty rains, and is of lines of men and women jumping and circling around each other. Clappers of wood are beaten.

This dance is found with the other tribes; the Suk call it Ny'olat.

Musical instruments do not seem to be found with the tribe. A form of single-stick (two sticks are used, one as a shield) is played; at this the Turkana are adepts. Two intricate forms of the universal African board game are played. different from the Bantu and Hamito-Semitic forms. Hunting is practically confined to the $N_{\boldsymbol{g}}$ 'abotok Turkana, and to the very poor of other sections. Animals are speared and trapped. Traps are of three kinds : the ordinary sapling and noose, the game pit, and a circular trap from which spokes go inwards but do not meet, leaving a small circle; the size is adapted for elephants downwards. The animal treads on the trap, which is placed over a hole; the trap is forced up the leg, and is attached by ropes of rhinoceros or other hide to a large $\log$ which impedes the animal's movements in the bush until it can be despatched. 
Arts and Crafts.-Iron work does not seem to be known, and spears and axes are purchased, mainly from the Jie, who obtain them from the Acholi, and also from the Suk when friendly. Skins are dressed for wear. Honey barrels are made from logs. Pillow stools are very accurately carved and made. Coarse pots are made for cooking. Natural gourds are used for milk, and also an oval wooden goblet which will not stand up, but, as the gourd, packs conveniently in the wicker donkey panniers. The women do intricate bead work. Hairdressing and exaggerated cattle branding might be described as pictorial.

Food.-The Turkana subsist mainly on meat, blood, and milk, of which they drink large quantities; certain parts of the animal eaten are the portion of the women, old and young men, and children. In times of scarcity edible berries are eaten. Game, small mammals (especially by children), and even donkeys are eaten; crocodiles but rarely; fish and land tortoises are used, and also monkeys. There is no prohibition against eating dead animals; in short, the diet is regulated by the circumstances of the person.

Millet and plants of the marrow variety are sometimes cultivated; meat is dried and beaten into a powder; tobacco is bighly prized, both for chewing and snuff, and that grown by the Hill Suk preferred. The fruit of Dom palm (Hyphaene Thebaica) is pounded into a meal. Millet beer and honey mead are used. They are not a drunken race. The hide, when not required, is cut up with the meat. Cattle urine is mixed with milk for digestive reasons.

Organisation.-The Turkana is very much a law to himself. The only authority is the "witch doctor," who rather confines his functions to advice as to the success of raids, grazing, and migrations. Count Teleki states that the Turkana have two of these. The camels are the sphere of the senior, the cattle, sheep, and goats the junior. There is reason to think that the father and son combine these functions, but it is not certain, and it cannot be argued that the office is hereditary. There is also a little evidence to state that the daughter of the present "Stock Adviser" dreams 
dreams. This functionary is known as the Emuron; he is not in contact with administration. It has been stated that the Turkana have a War Chief; the present aspirant has no following, other than a gang of desperadoes, and is not a tribal functionary.

The Turkana divide into two, mainly geographical, sections :-

I. The $N y^{\prime}$ issir, from essir, smartness in dress, which subdivide into:-

a. The Ny'emonia, from emoni, bush.

b. The Ny'eseto.

c. The Mboicheros, from eboroichu, dirty, said to refer to their villages; they are poverty-stricken, and live on fish and Dom palm meal on Lake Rudodf.

d. The Lisiga, from isiga, slightly built.

2. The $\mathrm{Ng}^{\prime}$ ebellai, from ebela, the curved sharp stick weapon carried by the Turkana, which subdivide into:-

a. $\mathrm{Ng}^{\prime}$ olio, from ng'olia (pl.), fish.

b. Ng'otonia.

Both the above have an admixture of Samburu blood.

c. $\mathrm{Ng}$ 'ataicha, from etaicha, a form of game trap.

d. $\mathrm{Ng}_{\mathrm{g}}$ amatak, from emathi, I drink, a reference to their more plentiful supply of water.

The $N y^{\prime}$ eseto and $\mathrm{Ng}_{\mathrm{g}}$ amatak have largely become independent of their sections.

Two other sections are found, the $\mathrm{Ng}^{\prime}$ atom, from atom, an elephant, and also a rifle, who have practically become a separate tribe near the Sudan-Abyssinian frontier; and the $\mathrm{Ng}_{\mathrm{g}}$ abotok, poor cultivators and hunters, somewhat localised near the Turkwell Gorge, of which each section has its complement.

The Turkana social divisions are :-

I. $N$ g'abanak, boys under 15 years.

2. $\mathrm{Ng}^{\prime}$ esurok, youths 15 to 20 years.

3. $N_{g}$ 'iliok, warriors 20 to 60 years. 
Subdividing into :-
a. Ng'walemongin, 21 to 30 years.
b. $N g^{\prime}$ echedomesiken, 30 to 35 years.
c. Ng'oiyaren, 35 to 40 years.
d. $\mathrm{Ng}^{\prime}$ etera, 40 to 45 years.
e. Ng'mergwara, 45 to 50 years.
f. $\mathrm{Ng}^{\prime}$ erowi, 50 to 60 years.

4. $\mathrm{Ng}_{\mathrm{g}}$ kasiko, men over 60 years.

These social divisions have been compiled by Mr. S. O. V. Hodge, and re-spelt.

The first and last do not accompany raids; the second as helpers, herds, and the like. Iron wire rings worn around the neck apparently mark the stages of manhood.

Women's social divisions are :-

1. Ng'abethe, girls.

2. Ng'ateruk, brides.

3. $\mathrm{Ng}_{\mathrm{g}}$ abero, wives.

4. $N g^{\prime}$ akima, old women.

Pregnancy before marriage is not uncommon, "illegitimate " children follow the mother, not the father, as the Suk; the young men and girls do not live together.

Totemism.-There is a system of totemistic ages, athapan, which are not cyclic, as with the Suk, and are separate from the totemistic clans. Many of the designations for these ages are found with the Karamoja.

These ages are :-

I. Ng'isiguru, thorns.

2. Ng'echomin, baboons, which were not killed or the skins worn save with this age's permission.

3. $\mathrm{Ng}_{\mathrm{g}}$ adogoi, monkeys, as above.

4. Ng'echelebuth, white stones. Members might dispossess others of these to sit upon.

5. $\mathrm{Ng}^{\prime}$ irionomor, pure black oxen. Assent sought before slaughter by others.

6. Ng'ethamuketh, unmudded hair. Absence of mudded coiffure resented in others.

7. $\mathrm{Ng}^{\prime}$ ababanga, ducks. Permission from these to kill. 
8. $N g^{\prime}$ ebuterok, bush pigs, as above.

9. Ng'omatheth, locusts, as above.

10. Uwabeto, eland, as above. This age has a right to black stones to sit upon.

I1. $\mathrm{Ng}^{\prime}$ echonodethekin, lame sheep. Permission from these to kill.

12. Ng'ebelakwera, broken spear shafts. This age when spearing oxen for food break the haft of the spear used.

13. Ng'irisai, leopards. Permission to kill from these, and also to kill elephants and hedgehogs.

14. $\mathrm{Ng}_{\mathrm{g}}$ 'tabene, guinea fowl. Permission to kill from these.

15. $\mathrm{Ng}$ 'angabwerin, standing water. Other ages should not smear themselves with the mud.

16. $N g^{\prime}$ omerichada, serval cats. Permission to kill from these.

17. Uwalanya, reeds, the plumes of which this age would appropriate for ornament.

18. $\mathrm{Ng}^{\prime}$ inamouie, hut-burners, the mischievous youths of the present age (1920).

These ages are consecutive. There are forgotten ages previous to the first; a few $\mathbf{N g}$ 'abuterok are said to be living, which is scarcely possible. Ages are usually associated with circumcision, which the Turkana do not follow. The totemistic taboos are not rigid, and often eluded; the relationship of a man to his age and its totem is as loose as that of the English youth to a football club. When youths consider their age should be named, they collect bullocks, call upon the elders, make a feast, and request a certain name, which is passed on throughout the Turkana sections with some bickering as to the exact designation of the age.

There is a system of totemistic clans which may not intermarry or cohabit. The father's clan is followed by both males and females; captives take the clan of the captor. Many of these totemistic clans ( $\mathrm{Ng}^{\prime}$ atergern) are found amongst the Karamojo. They are :-

I. $\mathrm{Ng}^{\prime}$ atogok, a sloe-like berry (Swahili, Mkunasi). This tree may not be cut save by members, who also may not eat or touch the Lesser Kudu.

2. $\mathrm{Ng}^{\prime}$ elelet, running water. The originator was carried 14 Vol, 20 
away by a flood-a rare occurrence. The clan may not eat or touch Grant's (? Robertsii, Brightsii, Petersii) gazelle.

3. Ng'eduyia, old cows. This clan may not eat the heart, lungs, liver, kidneys, entrails, etc., of oxen.

4. $\mathrm{Ng}$ 'etarobokolon, suns, from a person who died of sunstroke. Totem animal unknown.

5. Ng'egoria, the striped. This clan shave their children's heads in stripes, and brand their cattle in the same fashion. They may not drink blood.

6. $\mathrm{Ng}$ 'etangor, the striped field-rats. They do not kill or eat this rat, and endeavour to prevent others.

7. $\mathrm{Ng}$ 'ekonom, fire-makers. They are said to be able to make a fire burn by their presence. They may not pick up articles found.

8. $\mathrm{Ng}$ 'atab, porridge. They may not look into the pots to gauge the porridge, nor eat porridge so estimated, under pain of blindness.

9. $N g$ 'ebonga, a certain wild fruit. This may not be eaten by these under fear of death from internal stoppage.

10. $\mathrm{Ng}$ 'araruk, the toothless. These may not eat the heads of any animals.

II. $N g^{\prime}$ 'ebuicho, ?

This list is probably not complete. The clan totems are more rigid than the age totems; husband and wife do not appear to call each other by the name of the clan, as with the Suk. Cattle are branded according to the clan.

Names.-Children receive names shortly after birth from the mother; these are generally of animals or objects, as ostrich, mosquito, beetle. Youths and men of ten take the name of their best bull or bullock, or a name implying the fashion into which its horns have been trained, as with the Jie, Dodoso, Karamojo, and Suk. A successful homicide may give rise to a new name, ending in moi or moi affixed to the original name, as with the tribes above. A man is not called "son of __" when directly or indirectly mentioned, as with the Masai and Nandi.

Religion.-No trace of a religion or future state has been noted; a word for a Supreme Being, Akuich, is given, but there is no further idea, and the word also means "above." 
There is a word for ghosts, sorai, said to be white wraiths with black hair; this word was formerly used to denote Europeans. No deity is invoked in oaths, which are generally obscene. Formal aaths or peace-making is by the presentation of white ostrich feathers by each of the tribes; or by the cutting in two of, it is said, a live donkey or dog ; or by walking over spears laid with their points together. Quarter is asked by proffering grass, and evidence of truth given by putting dust to the lips. No oath can be considered unbreakable. These customs are found with the other tribes.

Psychology.-The Turkana is generally loyal to his tribe and section, and at present disloyal to Europeans engaged in administration. He has not a fanatic contempt of death; is a brave fighter when necessary, and does not expose himself to danger unnecessarily. In raids and homicides he does not spare women or children, arguing that the woman is the mother of the child and the child the parent of the man. $\mathrm{He}$ does not exhibit any great cunning of forethought in his lies. $\mathrm{He}$ is quarrelsome and sulky. He is bold and adventurous, indifferent to fatigue and suffering. He is moderately generous when rich, and extremely grasping when poor. He has little or no tribal organisation to guide him; he has an indomitable spirit, and quite probably when it has become possible to gain the tribal confidence his negative qualities will become positive, and he will develop as a stockman and trained soldier, and justify the sneaking regard most Europeans have for his manhood and virility.

JUXON BARTON. 